\title{
Barium/Cobalt@Polyethylene Glycol Nanocomposites for Dye Removal from Aqueous Solutions
}

\author{
Somayeh Rahdar ${ }^{1}$, Abbas Rahdar ${ }^{2, * \mathbb{D}}$, Mostafa Sattari ${ }^{3}$, Laleh Divband Hafshejani ${ }^{4}$, Athanasia K. Tolkou ${ }^{5}$ (D) \\ and George Z. Kyzas 6,*(D)
}

1 Department of Environmental Health, Zabol University of Medical Sciences, Zabol 9861615881, Iran; rahdar89@gmail.com

2 Department of Physics, Faculty of Science, University of Zabol, Zabol 538-98615, Iran

3 Department of Mathematics, Faculty of Science, University of Zabol, Zabol 538-98615, Iran; msattari.b@gmail.com

4 Department of Environmental Engineering, Faculty of Water and Environmental Engineering, Shahid Chamran University of Ahvaz, Ahvaz 6135743136, Iran; 1.divband@scu.ac.ir

5 Department of Chemistry, Aristotle University of Thessaloniki, 54124 Thessaloniki, Greece; tolkatha@chem.auth.gr

6 Department of Chemistry, International Hellenic University, 65404 Kavala, Greece

* Correspondence: a.rahdar@uoz.ac.ir (A.R.); kyzas@chem.ihu.gr (G.Z.K.); Tel.: +30-2510-462218 (G.Z.K.)

check for

updates

Citation: Rahdar, S.; Rahdar, A.; Sattari, M.; Hafshejani, L.D.; Tolkou, A.K.; Kyzas, G.Z.

Barium/Cobalt@Polyethylene Glycol Nanocomposites for Dye Removal from Aqueous Solutions. Polymers 2021, 13, 1161. https://doi.org/ $10.3390 /$ polym 13071161

Academic Editor: George

Z. Papageorgiou

Received: 17 March 2021

Accepted: 2 April 2021

Published: 5 April 2021

Publisher's Note: MDPI stays neutral with regard to jurisdictional claims in published maps and institutional affiliations.

Copyright: (c) 2021 by the authors. Licensee MDPI, Basel, Switzerland This article is an open access article distributed under the terms and conditions of the Creative Commons Attribution (CC BY) license (https:// creativecommons.org/licenses/by/ $4.0 /)$.

\begin{abstract}
Dyes are known as one of the most dangerous industrial pollutants which can cause skin diseases, allergy, and provoke cancer and mutation in humans. Therefore, one of the important environmental issues is the effective removal of dyes from industrial wastewater. In the current work, $\mathrm{BaFe}_{12} \mathrm{O}_{19} / \mathrm{CoFe}_{2} \mathrm{O}_{4} @$ polyethylene glycol (abbreviated as BFO/CFO@PEG) nanocomposite was synthesized and evaluated regarding its capacity for adsorptive removal of a model dye Acid Blue 92 (denoted as AB92) from aqueous solutions. The characteristics of the prepared nanocomposite was determined by tests such as X-ray diffraction (XRD), scanning electron microscope (SEM), vibration sample magnetization (VSM), and Fourier transform infrared spectroscopy (FTIR). The effects of conditional parameters including $\mathrm{pH}(2-12)$, initial concentration of dye (20-100 $\mathrm{mg} / \mathrm{L})$, adsorbent dosage $(0.02-0.1 \mathrm{~g} / \mathrm{L})$ and contact time $(0-180 \mathrm{~min})$ on the adsorption of dye were investigated and then optimized. The results indicated that with the increase of the adsorbent dosage from 0.02 to $0.1 \mathrm{~g} / \mathrm{L}$, the removal efficiency increased from $74.1 \%$ to $78.6 \%$, and the adsorbed amount decreased from 148.25 to $31.44 \mathrm{mg} / \mathrm{g}$. The maximum removal efficiency $(77.54 \%)$ and adsorption capacity $(31.02 \mathrm{mg} / \mathrm{g}$ ) were observed at $\mathrm{pH}$ 2. Therefore, the general optimization conditions revealed that the maximum adsorption efficiency of dye was obtained in condition of initial concentration of $20 \mathrm{mg} / \mathrm{L}$, contact time of $1 \mathrm{~h}$ and $\mathrm{pH}$ of solution equal 2 . The adsorption isotherm and kinetic data were evaluated using a series of models. The pseudo-second order kinetic model and Freundlich isotherm model show the best fitting with experimental data with $\mathrm{R}^{2} \sim 0.999$.
\end{abstract}

Keywords: dyes; acid blue 92; nanocomposite; adsorption; isotherm; kinetics

\section{Introduction}

Various industries - such as textile, plastic, paper, and food industries - employ over 100,000 types of commercial dyes. Around $10-15 \%$ of all dyes used globally, which is equivalent to 280,000 tons, enter the environment through the wastewater discharge from factories [1-3]. The consumed dyes are categorized into three groups: non-ionic, cationic, and anionic, which are toxic at low concentrations and have high suitability in water resources. Also, synthetic dyes are categorized as organic dyes which have a complex aromatic molecular structure and are hardly biodegradable [4-6]. Therefore, entrance of synthetic dye molecules to water resources has threatened the environment and general health of humans [7]. The high concentration of dyes in wastewaters has negative effects on 
visibility and with the diminished sunlight penetration into water it impairs photosynthesis, jeopardizing the life of aquaculture, which also interferes with solubility of gases [8,9]. In addition, the chemicals present in dye wastewaters are toxic which cause carcinogenicity, mutagenicity, and teratogenicity in biological species and aquaculture [8]. Therefore, dyes should be removed, for which biological, chemical, and physical methods are available [10]. Their application is evaluated and compared based on critical parameters such as cost, simplicity in design and operation, availability, toxicity of materials, sensitivity, and efficiency [11]. However, most of the mentioned processes are expensive, and thus economical methods should be used.

Recently, hairy nanocellulose, a type of biorenewable cellulose nanoparticles, has been synthesized for methylene blue removal from wastewater by an environmentally friendly and economical procedure, providing an uptake capacity higher than the existing values in the literature [12]. Cellulose nanoparticles were also used for membrane modification, hence, nanocellulose-enabled membranes were tested in dye removal experiments, exhibiting a dye removal efficiency of 70-80\% [13]. In addition, modified Cellulose acetate nanofibrous membranes were applied efficiently for removing methylene blue (MB) from water [14]. Furthermore, metal-organic frameworks (MOFs) was tested for anionic and cationic dyes removal by adsorption and a zirconium-metalloporphyrin MOF [15], or a polyoxometalate (POM) composite [2], were used to enhance their adsorption capacity in aqueous solution. Dye adsorption on $\mathrm{CO}_{2}$-activated chitosan was studied recently, providing a simple, economical, and quick operation [16].

Adsorption is widely used in water and wastewater treatment [17-28], which is one of the most effective technology [29-34]. Adsorption process between liquid and solid phase is strongly affected from temperature [35]. Recently, various nanomaterials have been synthesized as absorbents to use for contaminant separation from liquid phase [36]. Nanoscale materials, due to their unique properties-such as large surface area, large number of reactive sites, small size, and high capacity of recovery-have shown excellent performance in solving of many problems related to water quality $[7,37]$.

Acid dyes are commonly used to dye some fibers such as synthetic polyamide, i.e., nylon; natural proteins, i.e., wool and silk; acrylics; and also a blend of these fibers [38]. These acid dyes owe their name to the fact that they are applied in acidic or neutral conditions. Although color index definition, in the category of acid dyes, considers also metal complex dyes and Cr-complex dyes, this article is limited to the classic acid dyes, those applied on wool, silk, and nylon. Commercially existing dyes are mainly acid based azo, anthraquinone or triphenyl methane dyes, with the most popular chromophore being the azo group. Despite the fact that there are several other acid dyes-like xanthane, azine, nitro, quinoline, indigoid, and carbolan-their commercial use is limited.

Regarding all these, this type of dye is more commonly applied in industrial wastewater, with the azo dyes covering the $70 \%$ of total dyes worldwide [39]. Their decomposition in the natural environment, becomes difficult due to the presence of various functional groups that have toxic, mutagenic, and carcinogenic effects [40] and therefore must be removed from the effluent before being discharged into natural water systems [41-45].

Hexagonal barium ferrites composites have been previously applied owing to the expectation of high remaining magnetization and high energy product by using micromagnetic calculations, high-density magnetic recording, microwave devices, and magnetofluid medicine [46]. Roy et al. (2009) examined the use of $\mathrm{BaFe}_{12} \mathrm{O}_{19} / \mathrm{Ni}_{0.8} \mathrm{Zn}_{0.2} \mathrm{Fe}_{2} \mathrm{O}_{4}$ composite powders finding out the effect of temperature coercivity [47]. Later, Radmanesh et al. (2012) studied the use of $\mathrm{SrFe}_{12} \mathrm{O}_{19} / \mathrm{Ni}_{0.7} \mathrm{Zn}_{0.3} \mathrm{Fe}_{2} \mathrm{O}_{4}$ composite powders, providing the alteration of the reduced remanence $\left(\mathrm{M}_{\mathrm{r}} / \mathrm{M}_{\mathrm{S}}\right)$ with the increase of weight fraction of the soft phase and explaining the exchange and bipolar interactions in coordinating the magnetic properties of nanocomposites [48]. These studies examine only the effect of different factors on magnetic properties. Beside the fact that there are several examples regarding the use of composite ferrites as adsorbents [49], the synthesized composite nanoferrite (barium/cobalt) has not been examined so far as an adsorbent. 
In the current study, $\mathrm{BaFe}_{12} \mathrm{O}_{19} / \mathrm{CoFe}_{2} \mathrm{O}_{4} @$ polyethylene glycol nanocomposites (abbreviated as $\mathrm{BFO} / \mathrm{CFO} @ \mathrm{PEG}$ ) were provided with sol-gel method as nanoadsorbents for the removal of a model dye pollutant, Acid Blue 92 (abbreviated as AB92), from aqueous solutions. The application of this nanocomposite to remove AB92 from effluents is novel and is not tested until now (based on literature screening). Synthetic dyes are one of the most dangerous type of dyes that found in industrial wastewater [50-58] and should to be reduced to allowable amount before being discharged into the environment [59]. Then, the effect of changing the parameters such as $\mathrm{pH}$, dye concentration, contact time, and dosage of adsorbent on the adsorption equilibrium and dye removal by $\mathrm{BFO} / \mathrm{CFO}$ nanocomposites were investigated. Finally, the adsorption kinetics and isotherm models have also been studied.

\section{Material and Methods}

\subsection{Materials}

Cobalt nitrate $\left(\mathrm{Co}\left(\mathrm{NO}_{3}\right)_{2} 6 \mathrm{H}_{2} \mathrm{O}\right)(99 \%$, supplied by Merck, Germany) barium nitrate $\left(\mathrm{Ba}\left(\mathrm{NO}_{3}\right)_{3}-9 \mathrm{H}_{2} \mathrm{O}\right)\left(99 \%\right.$, supplied by Merck), iron nitrate $\left(\mathrm{Fe}\left(\mathrm{NO}_{3}\right)_{3} \cdot 9 \mathrm{H}_{2} \mathrm{O}\right)(99 \%$, supplied by Merck), poly(ethylene glycol) (Sigma-Aldrich (Berlin, Germany)), citric acid $\left(\mathrm{C}_{6} \mathrm{H}_{8} \mathrm{O}_{7}\right)$, and sodium hydroxide $(\mathrm{NaOH})$ were applied as received. In all experiment steps, deionized water was used. In this study, in order to prepare the experimental solution containing dye as contaminant, $\mathrm{AB} 92$ (anazolene sodium, $\mathrm{C}_{26} \mathrm{H}_{16} \mathrm{~N} 3 \mathrm{Na3}$ 10S3) was purchased from AlvanSabet Corporation (Hamadan, Iran).

Figure 1 shows the chemical structure of (AB92) which is known commercial salt consisting of dye and inert product with pure dye content was $40 \%$.

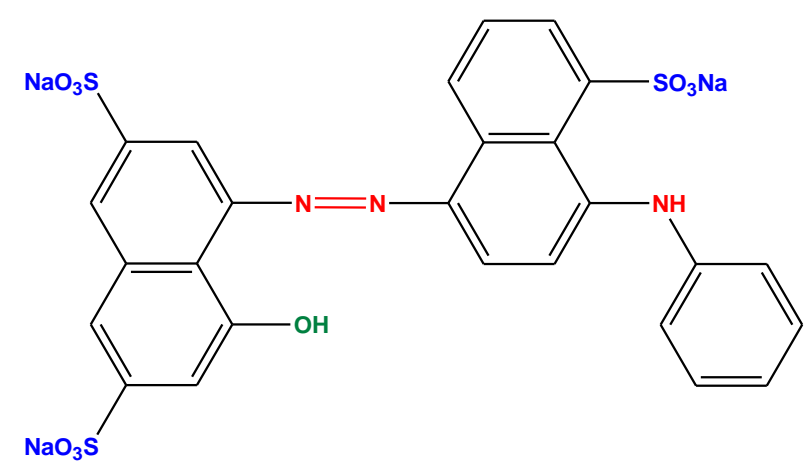

Figure 1. Structure of AB92.

\subsection{Synthesis}

$\mathrm{BaFe}_{12} \mathrm{O}_{19} / \mathrm{CoFe}_{2} \mathrm{O}_{4} @$ polyethylene glycol nanocomposites (BFO/CFO@PEG nanocomposites) synthesized using via sol-gel method [46].

\subsection{Characterization Techniques}

Scanning electron microscopy (SEM) images were performed at Jeol JSM-6390 LV (Jeol, Tokyo, Japan). The accelerating voltage was $15.00 \mathrm{kV}$ and the scanning was performed in situ on a sample powder. EDAX analysis was done at magnification $10 \mathrm{~K}$ and led to the maps of elements and elemental analysis. The FTIR spectra of the samples were taken with a PerkinElmer-FT-IR/NIR spectrometer using KBr disks prepared by mixing $0.5 \%$ of finely ground carbon sample in $\mathrm{KBr}$. Pellet made of pure $\mathrm{KBr}$ was used as the reference sample for background measurements. The spectra were recorded from 4000 to $400 \mathrm{~cm}^{-1}$ at a resolution of $4 \mathrm{~cm}^{-1}$. The spectra presented are baseline corrected and converted to the transmittance mode. Also, thermal analysis was carried out using a TA Instrument thermal analyzer (SDT). The instrument had the following settings: (i) heating rate of $10 \mathrm{~K} / \mathrm{min}$, and (ii) flow rate of nitrogen atmosphere equal to $100 \mathrm{~mL} / \mathrm{min}$. Approximately $25 \mathrm{mg}$ of sample was used for each measurement. Moreover, X-ray powder diffraction (XRD) patterns were recorded on a D8 Advance X'Pert X-ray diffractometer (Bruker, Massachusetts, USA) 
with a $\mathrm{CuK} \alpha$ radiation for crystalline phase identification. The sample was scanned from 20 to $80^{\circ}$. The magnetic behavior of the samples was studied using vibrating sample magnetometry (VSM, Kavir Precise Magnetic, Karshan, Iran). Zeta potential measurements were performed using a zeta sizer (Nano Zs, Nano series Malvern instruments, Malvern Panalytical, Cambridge, UK). Measurements were taken in water and PBS. Zeta potential measurements were done three times for each sample at 30 electrode cycles.

\subsection{Adsorption Experiments}

In this study, batch condition was used for all adsorption experiments. In each step of adsorption process, the initial and final concentrations of dye in experimental solutions were measured by UV-vis spectrophotometer (Shimadzu Model, CE-1021, UK) at $571 \mathrm{~nm}$ $\left(\lambda_{\max }\right)$. Also, the MIT65 $\mathrm{pH}$ meter was applied for measure of solution $\mathrm{pH}$.

The dye removal percentage (Equation (1)) and its adsorption capacity (Equation (2)) by the BFO/CFO@PEG nanocomposites were determined as

$$
\begin{aligned}
\text { Removal } & =\left(\frac{\mathrm{C}_{0}-\mathrm{C}_{\mathrm{e}}}{\mathrm{C}_{0}}\right) \cdot 100 \% \\
\mathrm{Q}_{\mathrm{e}} & =\frac{\left(\mathrm{C}_{0}-\mathrm{C}_{\mathrm{e}}\right) \mathrm{V}}{\mathrm{m}}
\end{aligned}
$$

where $C_{e}$ and $C_{0}$ are the equilibrium and initial concentrations of $A B 92(\mathrm{mg} / \mathrm{L})$, respectively, $\mathrm{V}$ is the volume of solution (L) and $\mathrm{m}$ is mass of BFO/CFO@PEG nanocomposites (g) [60].

All adsorption experiments were conducted in triplicate and finally the mean value are reported [61]. For preparation of the stock dye aqueous solution of $1000 \mathrm{mg} / \mathrm{L}, 1 \mathrm{~g}$ of dye was added to a $1 \mathrm{~L}$ volumetric flask.

For the determination of dye solution and its mechanism in each particular $\mathrm{pH}$, $0.1 \mathrm{~g} / \mathrm{L}$ synthesized BFO/CFO@PEG nanocomposites were mixed with $50 \mathrm{~mL}$ of dye solution $(80 \mathrm{mg} / \mathrm{L})$. Then the $\mathrm{pH}$ value of solution was adjusted in range of 2 to 12 by using $\mathrm{HNO}_{3}(0.01 \mathrm{~mol} / \mathrm{L})$ and $\mathrm{NaOH}(0.01 \mathrm{~mol} / \mathrm{L})$. The suspensions were shaken for $40 \mathrm{~min}$ at $25^{\circ} \mathrm{C}$ (water bath (Julabo SW-21C)). The agitation rate was adjusted at $150 \mathrm{rpm}$, because over this value the adsorption is not increased, based on results of preliminary tests. As in this study, optimum $\mathrm{pH}$ was found in $\mathrm{pH}=2$, this value was selected for next series of experiments.

In order to investigate the effect of initial dye concentration on its adsorption process by synthesized adsorbent, $1 \mathrm{~g}$ BFO/CFO@PEG nanocomposites was mixed with $50 \mathrm{~mL}$ of dye solution in different initial concentration (20-100 mg/L). After that the suspensions were agitation with speed of $150 \mathrm{rpm}$ for $40 \mathrm{~min}$ at $25^{\circ} \mathrm{C}$.

In equilibrium experiment, the effect of initial concentration was investigated by adding $0.1 \mathrm{~g} / \mathrm{L}$ of BFO/CFO@PEG nanocomposites with $50 \mathrm{~mL}$ solution contain different concentrations of dye $(20-100 \mathrm{mg} / \mathrm{L})$. Similar to the pervious step, $\mathrm{pH}=2$, contact time $=45 \mathrm{~min}$, agitation rate $=150 \mathrm{rpm}$, and temperature of experiment $=25^{\circ} \mathrm{C}$ were selected.

In this study, experiments related to contact time $(5,15,30,45,60,90,120,150$, and $180 \mathrm{~min}$ ) in adsorption kinetic studies were performed by adding $0.1 \mathrm{~g} / \mathrm{L}$ of synthesized adsorbent with $50 \mathrm{~mL}$ of dye solution. Then samples were shaken with agitation rate of $150 \mathrm{rpm}$, at $\mathrm{pH}=2$ and temperature of $25^{\circ} \mathrm{C}$.

The experiments of dosage adsorbent effect on dye adsorption were conducted by adding $0.02-0.1 \mathrm{~g} / \mathrm{L}$ of BFO/CFO@PEG nanocomposites with $50 \mathrm{~mL}$ of dye solution $(80 \mathrm{mg} / \mathrm{L})$. The suspension were agitated with speed of $150 \mathrm{rpm}$ for $40 \mathrm{~min}$ at $\mathrm{pH}=2$ and temperature of $25^{\circ} \mathrm{C}$. After adsorption and before analysis, the solutions were filtered by using membrane filter with a pore size of $0.45 \mu \mathrm{m}$ in order to separate the nanocomposites (adsorbent materials) from the supernatant. The experimental design for adsorption experiments was briefly presented in Table 1 . 
Table 1. Experimental conditions AB92 adsorption from aqueous solutions by BFO/CFO@PEG nanocomposites.

\begin{tabular}{ccccccc}
\hline Experiment & $\mathbf{p H}_{\mathbf{i}}$ & $\mathbf{T}\left({ }^{\circ} \mathbf{C}\right)$ & $\mathbf{C}_{\mathbf{0}}(\mathbf{m g} / \mathbf{L})$ & $\mathbf{N}(\mathbf{r p m})$ & $\mathbf{t}(\mathbf{m i n})$ & $\mathbf{m} / \mathbf{V}(\mathbf{g} / \mathbf{L})$ \\
\hline Effect of pH & $2-12$ & 25 & 80 & 150 & 40 & 0.1 \\
Effect of dosage & 2 & 25 & 80 & 150 & 40 & $0.02-0.10$ \\
Effect of contact time & 2 & 52 & 80 & 150 & $0-180$ & 0.06 \\
Effect of initial dye & 2 & 25 & $20-100$ & 150 & 180 & 0.1 \\
concentration & 2 & & & & \\
\hline
\end{tabular}

\section{Results and Discussion}

\subsection{Characterizations}

Figure 2 presents the size distribution of the prepared BFO/CFO@PEG (peak at 190 $\mathrm{nm}$ ), while Figure 3 shows the XRD pattern of BFO/CFO@PEG nanocomposites. The presence of hexagonal $\mathrm{BaFe}_{12} \mathrm{O}_{19}$ (JCPDS\# 00-043-0002) and cubic spinel CoFe $\mathrm{O}_{4}$ (JCPDS\# 00-022-1086) is clear. The mean of crystallite size D (nm) of nanocomposite was determined as 75-87 nm, according to (311) plane reflection from the XRD pattern using Debye-Scherrer equation (Equation (3)).

$$
\mathrm{D}=\frac{\mathrm{K}_{\mathrm{s}} \cdot \lambda}{\mathrm{B} \cdot \cos \theta}
$$

where $K_{s}$ is a constant, $\lambda(\mathrm{nm})$ is wavelength, $B$ is the peak width of half-maximum (rad), and $\theta$ is the diffraction angle. Note that for $\mathrm{CuKa}$ the relative constant values are $\mathrm{K}_{\mathrm{s}}=0.9$ and $\lambda=0.15405 \mathrm{~nm}$.

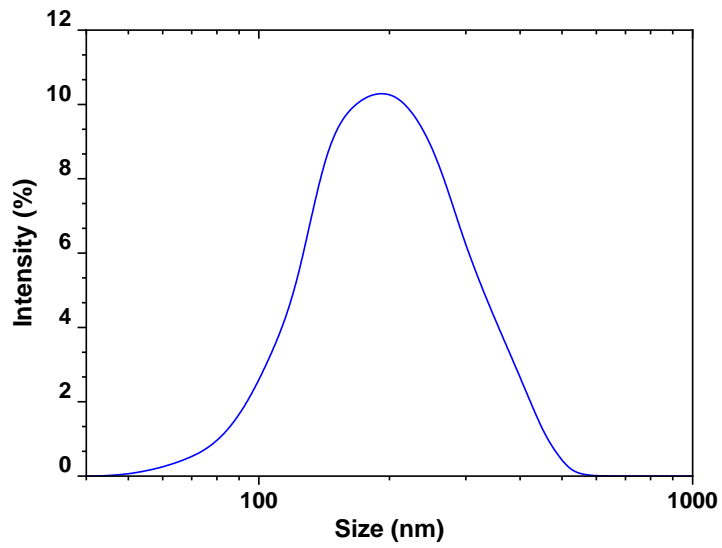

Figure 2. Size distribution of the the prepared nanocomposite.

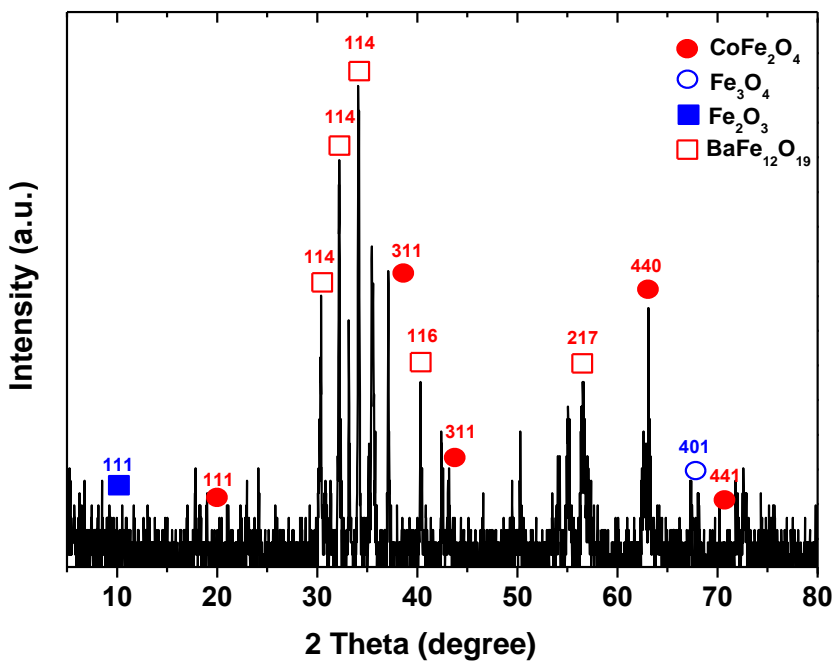

Figure 3. XRD pattern of BFO/CFO@PEG nanocomposites. 
VSM technique was applied to investigate the magnetic behavior of BFO/CFO@PEG nanocomposite, as illustrated in Figure 4. The ferromagnetism property of nanocomposite, confirmed by the magnetic hysteresis loop. As depicted from Figure 4, there is a VSM plot exhibited a value of $53 \mathrm{emu} / \mathrm{g}$ regarding the saturation magnetization of BFO/CFO@PEG. This results also confirmed from the relative literature, concerning the pure magnetite colloidal nanocrystals (36.941 emu/g) [62]. Noticeably, by using an external magnetic field, it can be observed that the nano-adsorbent can be separated relatively easily from the supernatant after adsorption process because of its magnetized properties.

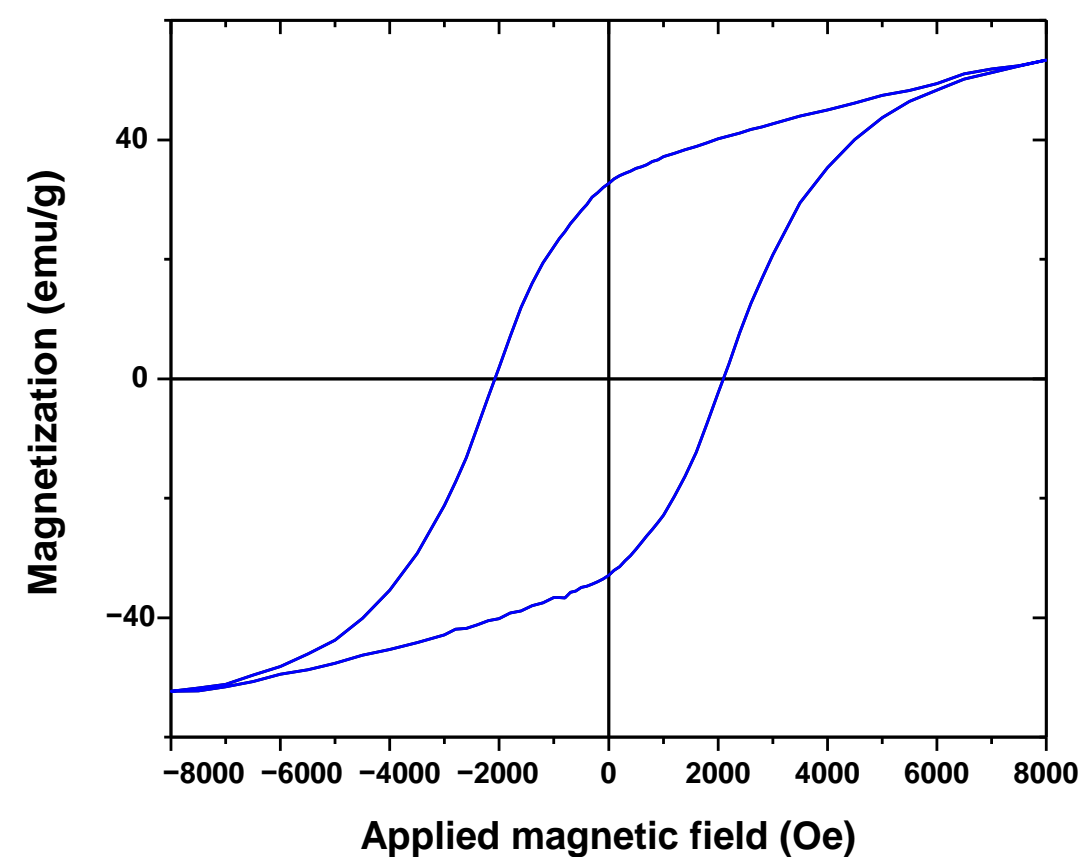

Figure 4. VSM plot of BFO/CFO@PEG nanocomposites.

Figure 5 presents the SEM image of BFO/CFO@PEG nanocomposites. As it can be shown, there are both cubic and hexagonal particles in the nanocomposite, which is in agreement with mineral composition determination by XRD analysis. However, the surface morphology is not smooth with some channels and abnormal cavities which can be attributed to the synthesis followed.

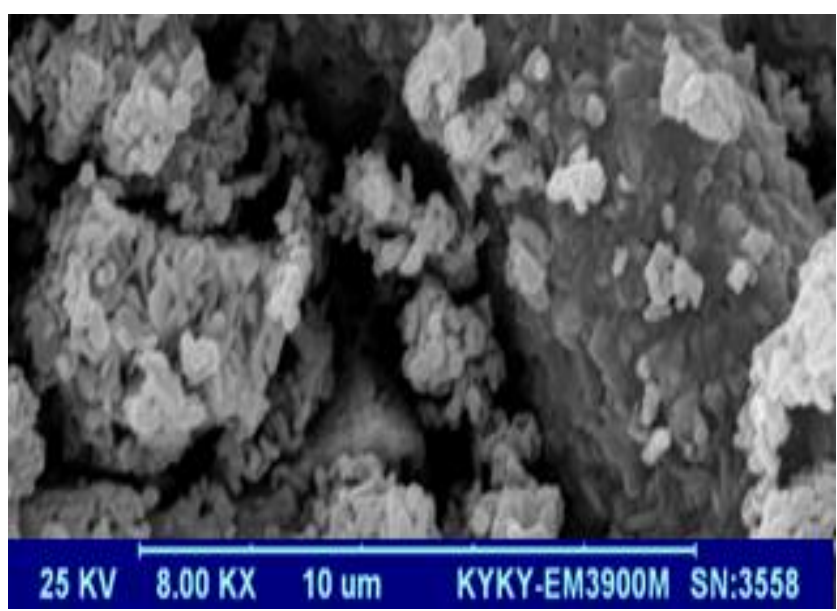

Figure 5. SEM image of BFO/CFO@PEG nanocomposites. 
The FTIR spectra of BFO/CFO@PEG nanocomposites before and after AB92 adsorption are given in Figure 6 . The broad peak at around $3463 \mathrm{~cm}^{-1}$ was attributable to the Hstretching, and the band at around $1641 \mathrm{~cm}^{-1}$ could be ascribe to $\mathrm{H}-\mathrm{OH}$ bending vibration These two peaks of nanocomposite before AB92 adsorption could be attributed to adsorbed water. The changes of the two peaks of nanocomposite after $\mathrm{AB} 92$ adsorption resulted from the presence of $\mathrm{AB} 92$ on the surface of nanocomposite. The fact that BFO/CFO@PEG was coated effectively to the magnetic $\mathrm{Fe}_{3} \mathrm{O}_{4}$ nanoparticles through electrostatic interaction, was proved by the appearance of a peak around $614 \mathrm{~cm}^{-1}$, indicative of the existence of $\mathrm{Fe}-\mathrm{O}$ stretching. After adsorption test it was observed that the peaks intensity increased significantly, which confirmed the adsorption of AB92 onto nanocomposite.

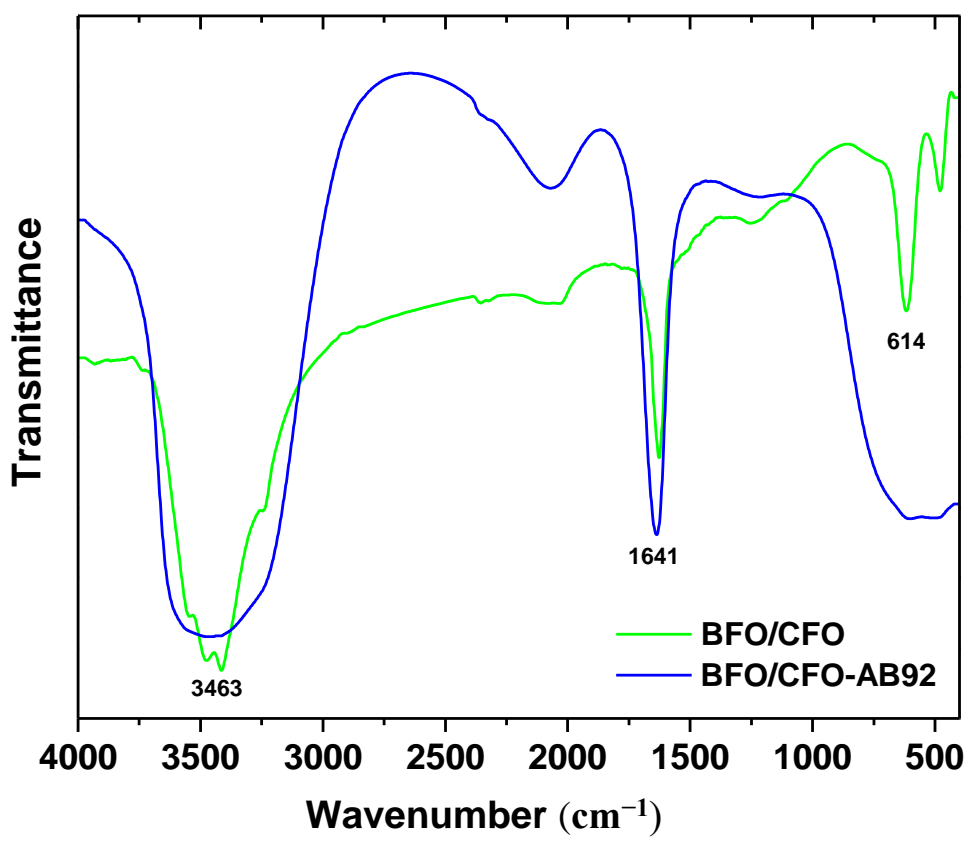

Figure 6. FTIR spectra of BFO/CFO@PEG nanocomposites before and after the adsorption experiment.

Thermal stability of BFO/CFO and PEG has been analyzed using TGA (Figure 7). TGA was performed in the temperature range of $25-700{ }^{\circ} \mathrm{C}$ to further confirm the existence of PEG on the surface of BFO/CFO nanoparticles and quantify the proportion of organic and inorganic phases. Pure PEG has started to combust at $\sim 330^{\circ} \mathrm{C}$ and completely combusted at $\sim 430^{\circ} \mathrm{C}$. Evidently, the combustion of PEG coated BFO/CFO nanoparticles starts earlier than the decomposition of pure PEG and continues up to $700{ }^{\circ} \mathrm{C}$. The earlier part of combustion curve is due to the evaporation of organic solvents and water. The second part (between 220 and $430{ }^{\circ} \mathrm{C}$ ) corresponds to decomposition of PEG and BFO/CFO composites into oxides. The temperature at which the decomposition of PEG coated BFO/CFO nanoparticles starts is lower than that of PEG alone, which indicates the catalytic effect of $\mathrm{BFO} / \mathrm{CFO}$ nanoparticles on the degradation of the PEG. Nanocomposites show a major weight loss of $\sim 20 \%$ over the temperature range of $25-700{ }^{\circ} \mathrm{C}$ due to the decomposition and combustion of PEG. This implies that nanocomposites have approximately $80 \%$ inorganic phase as $\mathrm{BFO} / \mathrm{CFO}$ nanoparticles. 


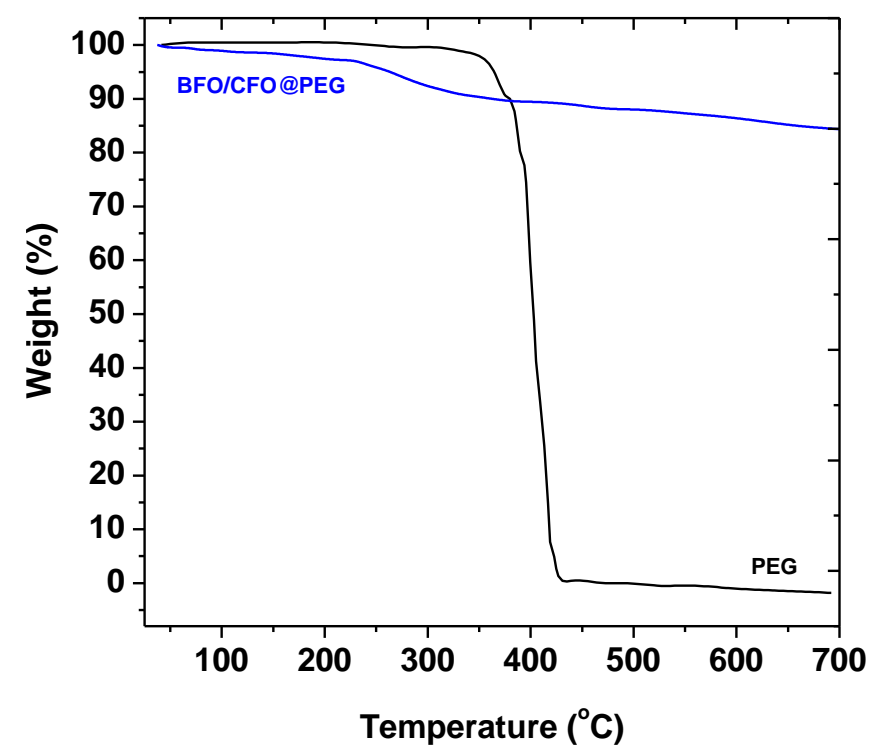

Figure 7. Thermal analysis of PEG and BFO/CFO@PEG.

The colloidal stability of the BFO/CFO and BFO/CFO@PEG materials was evaluated by zeta potential measurements. The zeta potential distribution of uncoated and coated sample using distilled water as a dispersant is shown in Figure 8. The zeta potential value in distilled water observed for the BFO/CFO@PEG $(-12.28 \mathrm{mV})$ is higher than the uncoated sample BFO/CFO $(-9.44 \mathrm{mV})$. This result shows that there is lesser aggregation of the $\mathrm{BFO} / \mathrm{CFO} @ \mathrm{PEG}$ nanocomposite in water compared to the BFO/CFO. High charge differences $(> \pm 10 \mathrm{mV})$ lead to greater interparticle repulsion [63] hence, there is enhancement of colloidal stability with increasing zeta potential values. Solubility in aqueous medium like water increases due to the hydrophilic ethylene glycol repeats in the PEG coating.

The results show that the BFO/CFO@PEG nanocomposites are relatively colloidally stable both in aqueous and physiological environments. These results imply that the BFO/CFO@PEG nanocomposites could maintain their dispersion stability and heating capacity in various physiological environments and thus have great potentials to be used in many applications.

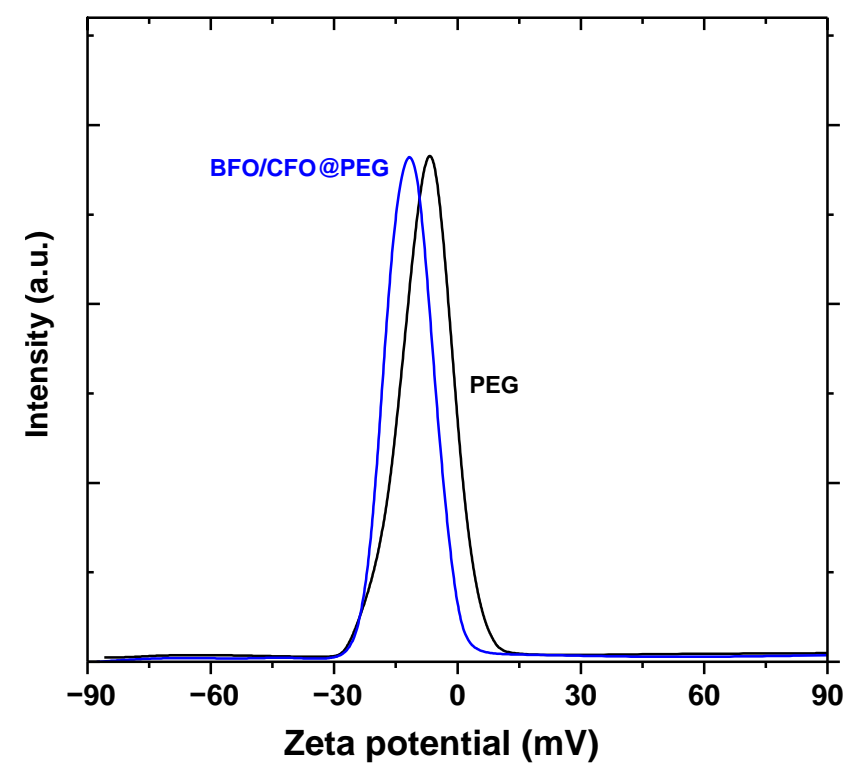

Figure 8. Zeta potential distribution of BFO/CFO and BFO/CFO@PEG nanoparticles (distilled water as dispersant). 


\subsection{Adsorption Evaluation}

\subsection{1. $\mathrm{pH}$ Effect}

Figure 9 illustrates the effect of initial $\mathrm{pH}$ of solutions on the adsorption of $\mathrm{AB} 92$ by BFO/CFO@PEG nanocomposite. The adsorption efficiency continuously increased with the reduction of initial solution $\mathrm{pH}$ from 2 to 12 . The maximum removal efficiency $(77.54 \%)$ and adsorption capacity $(31.02 \mathrm{mg} / \mathrm{g})$ were observed at $\mathrm{pH} 2$. The above finding can be easily explained taking into consideration that $\mathrm{pH}$ can change the superficial chemistry of nanoparticles. Therefore, under acidic conditions, $\mathrm{H}^{+}$ions accumulated on the surface of BFO/CFO@PEG nanocomposites [64]. These ions caused momentary neutralization of the negative charge of the nanoparticle surface by developing a buffer effect [65]. Meanwhile, the reduction of $\mathrm{pH}$ also provided the conditions for bonding negative sulfonate groups of AB92 molecules [66]. The reduction of surface negative charge posed a positive effect on adsorption of $\mathrm{AB} 92$ onto $\mathrm{BFO} / \mathrm{CFO} @ \mathrm{PEG}$ nanocomposites.

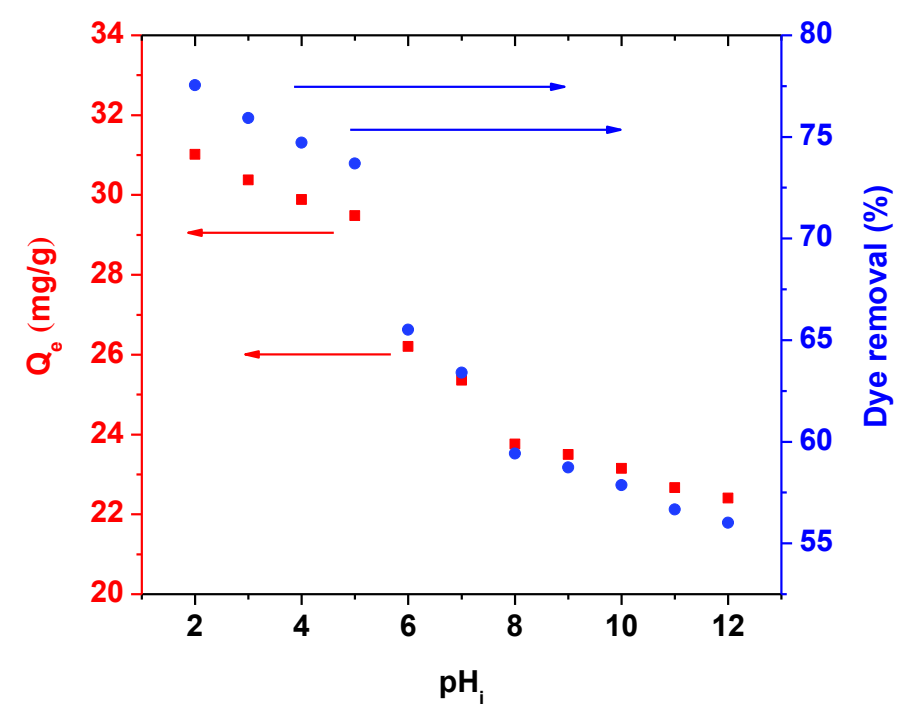

Figure 9. Effect of initial $\mathrm{pH}$ of solution on $\mathrm{AB} 92$ adsorption by BFO/CFO nanocomposites.

\subsubsection{Effect of Adsorbent Dosage}

Figure 10 shows the effect of adsorbent dosage on the adsorption of AB92 by BFO/CFO@PEG nanocomposites. The results indicated that with the increase of the adsorbent dosage from 0.02 to $0.1 \mathrm{~g} / \mathrm{L}$, the removal efficiency increased from 74.1 to $78.6 \%$, and the adsorbed amount decreased from 148.25 to $31.44 \mathrm{mg} / \mathrm{g}$. At the adsorbent dosage of $0.06 \mathrm{~g} / \mathrm{L}$, relatively high removal efficiency $(77.76 \%)$ and adsorption capacity $(51.84 \mathrm{mg} / \mathrm{g})$ were achieved. The increase of adsorbent's dosage means the increased number of active sites and the available surface centers of nanocomposite, causing the expected improvement of removal efficiency [61,67]. Meanwhile, the adsorbed amount of nanocomposite reduces by increasing the dosage, as some available sites on the absorbent surface had not been saturated and the adsorbate to absorbent ratio declined $[68,69]$. As the reactivity of nanocomposites are high, with increasing in the adsorbent dosage, adsorbent particle may be aggregated. Therefore their surface area and available adsorption sites on synthesized adsorbent will be reduced and finally AB92 adsorption decrease. 


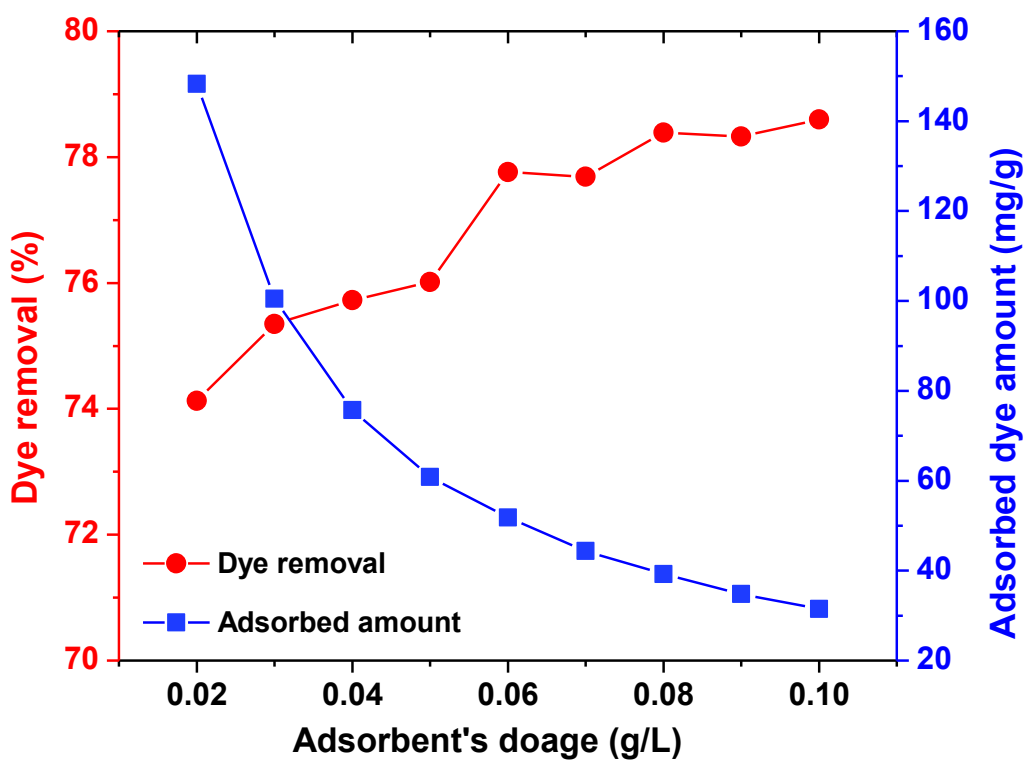

Figure 10. Effect of adsorbent dosage on $\mathrm{AB} 92$ adsorption by BFO/CFO nanocomposites.

\subsubsection{Isotherms and Kinetics}

Figure 11 shows the effectiveness of the adsorption of AB92 by BFO/CFO@PEG nanocomposite, taking into account the effect of contact time and initial dye concentration. As depicted, when the initial concentration was low, a rapid adsorption of the dye molecules on the surface of the nanocomposite was observed, while with the increasing of concentration a saturation was detected on the surface, thereby reducing the removal efficiency [70]. Figure 9 also indicated the adsorption tended to be equilibrium after $60 \mathrm{~min}$, and after that, the elevation of removal efficiency was limited.

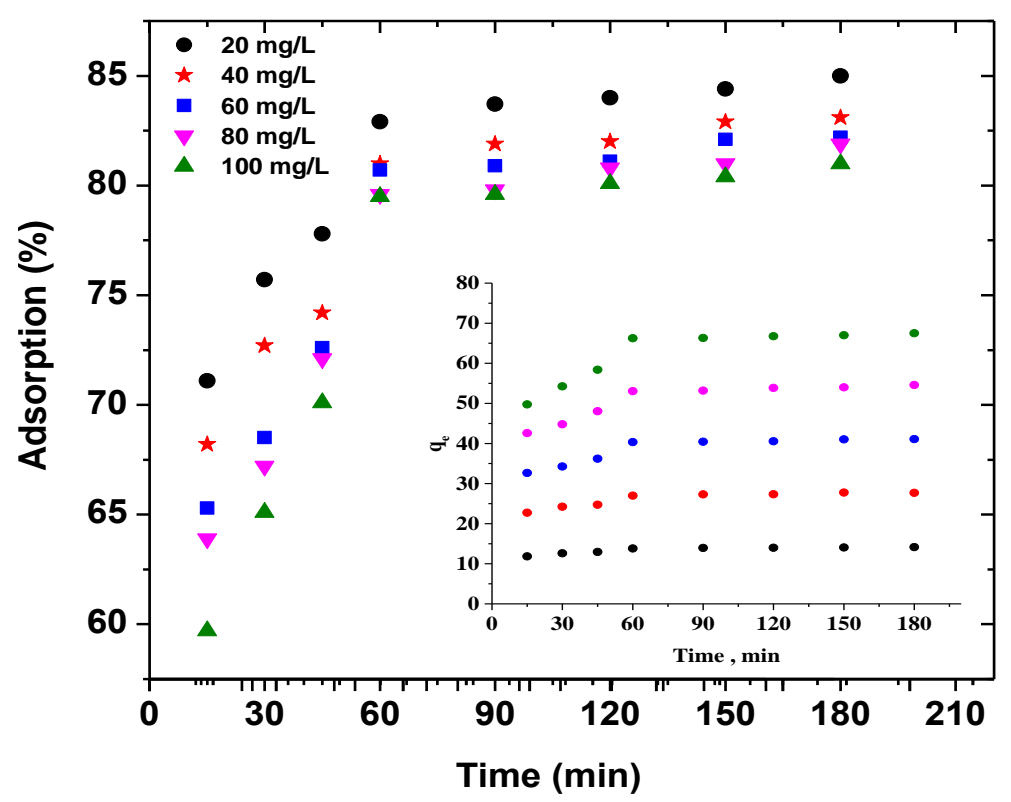

Figure 11. Effect of contact time and initial dye concentration on the adsorption of AB92 by BFO/CFO@PEG nanocomposite.

\subsubsection{Isotherm Models}

The isotherm of dye adsorption on BFO/CFO@PEG nanocomposite was investigated with different available models such as Langmuir, Freundlich, Temkin, and DubininRadushkevich. Also the goodness of applied models was investigated by coefficient of 
determination $\left(\mathrm{R}^{2}\right)$. When the adsorption sites of the adsorbents are uniform and the adsorbent surface is homogenous, there will be equal energy and enthalpy for all adsorbate molecules in the adsorption process. The linear of Langmuir model is given below [71].

$$
\frac{1}{q_{e}}=\frac{1}{q_{m}}+\left(\frac{1}{q_{m} K_{L}}\right) \frac{1}{C_{e}}
$$

where $\mathrm{q}_{\mathrm{e}}(\mathrm{mg} / \mathrm{g})$ is the amount of dye adsorbed per unit weight of BFO/CFO@PEG nanocomosite at equilibrium time, $\mathrm{C}_{\mathrm{e}}(\mathrm{mg} / \mathrm{L})$ is the equilibrium concentration of dye in solution, $\mathrm{q}_{\mathrm{m}}(\mathrm{mg} / \mathrm{g})$ is the maximum adsorption capacity of BFO/CFO@PEG nanocomosite, and $\mathrm{K}_{\mathrm{L}}(\mathrm{L} / \mathrm{mg})$ is the Langmuir equilibrium constant.

However, if the nanoparticle surface is heterogenous, Freundlich relation obtained by measuring the amount of adsorbed material at different pressures offers a better description of data [72].

$$
\log \left(\mathrm{q}_{\mathrm{e}}\right)=\frac{1}{\mathrm{n}} \log \left(\mathrm{C}_{\mathrm{e}}\right)+\log \left(\mathrm{K}_{\mathrm{F}}\right)
$$

where $K_{F}(\mathrm{mg} / \mathrm{g}) .(\mathrm{L} / \mathrm{g})^{\mathrm{n}}$ is the constant of equilibrium adsorption of Freundlich and $\mathrm{n}$ is the heterogeneity factor.

Temkin model is obtained based on indirect interaction of the adsorbent and adsorbate [73]

$$
\mathrm{q}_{\mathrm{e}}=\mathrm{B} \ln \left(\mathrm{K}_{\mathrm{T}}\right)+\mathrm{B} \ln \left(\mathrm{C}_{\mathrm{e}}\right)
$$

where $\mathrm{B}$ is related to the heat of adsorption $(\mathrm{L} / \mathrm{g})$, and $\mathrm{K}_{\mathrm{T}}$ is dimensionless Temkin isotherm constant.

Type of dye adsorption on the BFO/CFO@PEG nanocomosite in nature (physical or chemical) was determined by using Dubinin-Radushkevich isotherm model [74].

$$
\log \left(\mathrm{q}_{\mathrm{e}}\right)=\ln \left(\mathrm{q}_{\mathrm{m}}\right)-\beta \cdot \varepsilon^{2}
$$

where $\mathrm{q}_{\mathrm{e}}(\mathrm{mg} / \mathrm{g})$ is the amount of dye adsorbed per unit weight of BFO/CFO@PEG nanocomosite at equilibrium time, $\mathrm{q}_{\mathrm{m}}(\mathrm{mg} / \mathrm{g})$ is the maximum adsorption capacity of BFO/CFO@PEG nanocomosite, $\beta\left(\mathrm{mol}^{2} / \mathrm{J}^{2}\right)$ is a coefficient of mean adsorption energy.

The parameters of isotherm models are presented in Table 2.

Table 2. Equilibrium parameters of fitting to various isotherm models.

\begin{tabular}{ccc}
\hline Isotherm Model & Parameters & \\
\hline \multirow{3}{*}{ Langmuir } & $\mathrm{K}_{\mathrm{L}}(\mathrm{L} / \mathrm{mg})$ & 0.02 \\
& $\mathrm{q}_{\mathrm{m}}(\mathrm{mg} / \mathrm{g})$ & 215.08 \\
& $\mathrm{R}^{2}$ & 0.998 \\
\hline \multirow{2}{*}{ Freundlich } & $\mathrm{K}_{\mathrm{F}}(\mathrm{mg} / \mathrm{g})$ & 4.64 \\
& $\mathrm{n}$ & 0.14 \\
& $\mathrm{R}^{2}$ & 0.999 \\
\hline \multirow{2}{*}{ Temkin } & $\mathrm{K}_{\mathrm{T}}$ & 5.046 \\
& $\mathrm{~B}$ & 0.032 \\
& $\mathrm{R}^{2}$ & 0.994 \\
\hline \multirow{2}{*}{ Dubinin-Radushkevich } & $\beta$ & 0.0142 \\
& $\mathrm{q}_{\mathrm{m}}(\mathrm{mg} / \mathrm{g})$ & 3.142 \\
& $\mathrm{R}^{2}$ & 0.959 \\
\hline
\end{tabular}

\subsubsection{Kinetic Models}

In this study, different kinetic models such as pseudo-first-order (Equation(8)), pseudosecond-order (Equation (9)), intraparticle diffusion (Equation (10)), and Ritchie (Equation (11)) 
were used to describe the dye adsorption kinetic data [75]. The linear forms of first-ordermodel and pseudo-second-order are presented as

$$
\begin{gathered}
\log \left(\mathrm{q}_{\mathrm{e}}-\mathrm{q}_{\mathrm{t}}\right)=\log \left(\mathrm{q}_{\mathrm{e}}\right)-\mathrm{t} \frac{\mathrm{k}_{1}}{2.303} \\
\frac{\mathrm{t}}{\mathrm{q}_{\mathrm{t}}}=\frac{1}{\mathrm{k}_{2} \mathrm{q}_{\mathrm{e}}{ }^{2}}+\mathrm{t} \frac{1}{\mathrm{q}_{\mathrm{e}}}
\end{gathered}
$$

where $\mathrm{q}_{\mathrm{t}}(\mathrm{mg} / \mathrm{g})$ is the amount of dye adsorbed on BFO/CFO@PEG nanocomposite at time $\mathrm{t}, \mathrm{q}_{\mathrm{e}}(\mathrm{mg} / \mathrm{g})$ is the amount of dye adsorbed on BFO/CFO@PEG nanocomposite at equilibrium time, $\mathrm{k}_{1}(1 / \mathrm{min})$ is the rate constant of the pseudo-first-order, and $\mathrm{k}_{2}$ $(\mathrm{g} / \mathrm{mg} \cdot \mathrm{min})$ is the rate constant of pseudo-second-order model.

Chemisorption of pollutant on the adsorbent is responsible for the pseudo-secondorder model.

The intraparticle diffusion kinetic model is used for investigating the mechanism of diffusion of dye in porous nanoparticles and with transferring dye molecules from the soluble phase into the pores as the stage for determining and controlling the adsorption rate.

$$
\mathrm{q}_{\mathrm{t}}=\mathrm{k}_{\mathrm{p}} \mathrm{t}^{1 / 2}+\mathrm{C}
$$

where $\mathrm{k}_{\mathrm{p}}\left(\mathrm{mg} / \mathrm{g}\right.$. $\left.\min ^{0.5}\right)$ is the rate constant of intraparticle diffusion and $\mathrm{C}(\mathrm{mg} / \mathrm{g})$ is the intercept which shows surface adsorption or effect of boundary layer.

The Ritchie kinetic model is presented as

$$
\frac{1}{q_{t}}=\frac{1}{t} \cdot\left(\frac{1}{q_{e} k_{r}}\right)+\frac{1}{q_{e}}
$$

where $\mathrm{q}_{\mathrm{t}}$ and $\mathrm{q}_{\mathrm{e}}(\mathrm{mg} / \mathrm{g})$ are the amount of dye adsorbed on BFO/CFO@PEG nanocomposite at time $t$ and equilibrium time, respectively and $\mathrm{k}_{\mathrm{r}}$ is the rate constant $(1 / \mathrm{min})$.

The parameters of all the kinetic models are presented in Table 3. In terms of $R^{2}$ values, the pseudo-second-order kinetic and Freundlich isotherm models showed the most satisfactory fits. Figures 12 and 13 illustrate the plots of the Freundlich isotherm and pseudo-second-order kinetic models, respectively.

Table 3. Kinetic parameters of fitting to various isotherm models.

\begin{tabular}{ccc}
\hline Kinetic Model & Parameters & \\
\hline & $\mathrm{k}_{1}(1 / \mathrm{min})$ & 1.001 \\
Pseudo-first-order & $\mathrm{q}_{\mathrm{e}}(\mathrm{mg} / \mathrm{g})$ & 1.024 \\
& $\mathrm{R}^{2}$ & 0.921 \\
\hline \multirow{3}{*}{ Pseudo-second-order } & $\mathrm{K}_{2}(\mathrm{~g} / \mathrm{mg} \cdot \mathrm{min})$ & 0.0177 \\
& $\mathrm{q}_{\mathrm{e}}(\mathrm{mg} / \mathrm{g})$ & 14.471 \\
& $\mathrm{R}^{2}$ & 0.9998 \\
\hline \multirow{2}{*}{ Intra-particle-diffusion } & $\mathrm{K}(\mathrm{mg} / \mathrm{g} \cdot \mathrm{min})$ & 0.23 \\
& $\mathrm{C}(\mathrm{mg} / \mathrm{g})$ & 11.409 \\
& $\mathrm{R}^{2}$ & 0.83 \\
\hline Ritchie & $\mathrm{k}_{\mathrm{r}}$ & 0.296 \\
& $\mathrm{q}_{\mathrm{e}}(\mathrm{mg} / \mathrm{g})$ & 14.347 \\
& $\mathrm{R}^{2}$ & 0.936 \\
\hline
\end{tabular}




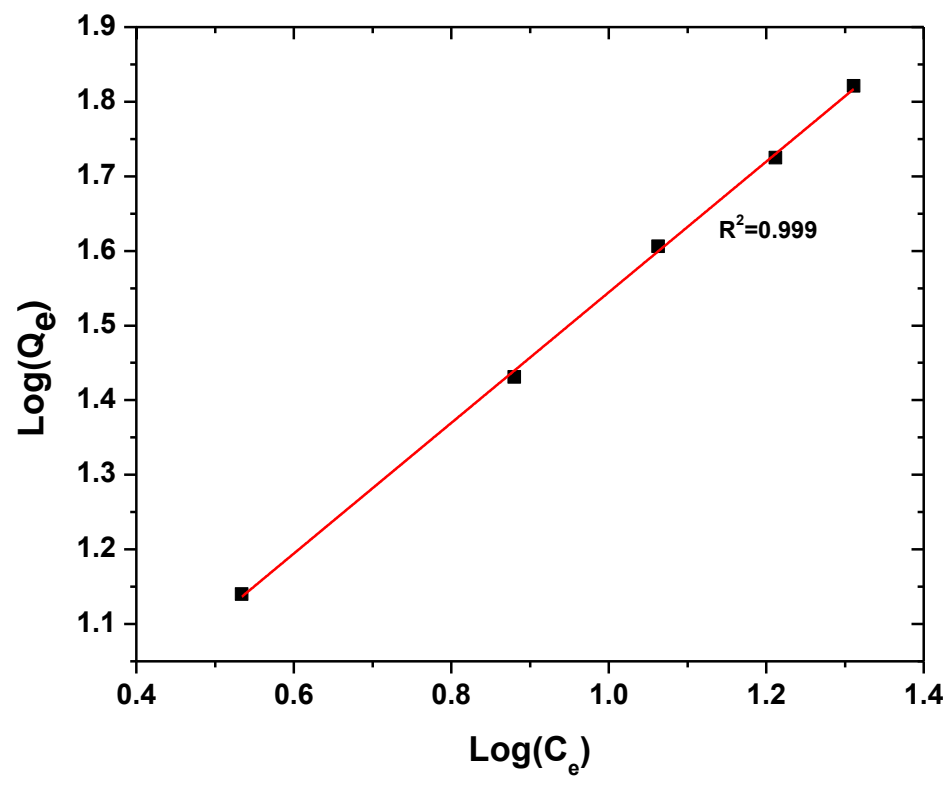

Figure 12. Freundlich isotherm plot of dye adsorption on BFO/CFO@PEG nanocomposites. Experimental condition: initial dye concentration $20-100 \mathrm{mg} / \mathrm{L}$, initial solution $\mathrm{pH} 2$, adsorbent dosage $0.06 \mathrm{~g} / \mathrm{L}$, and contact time $40 \mathrm{~min}$.

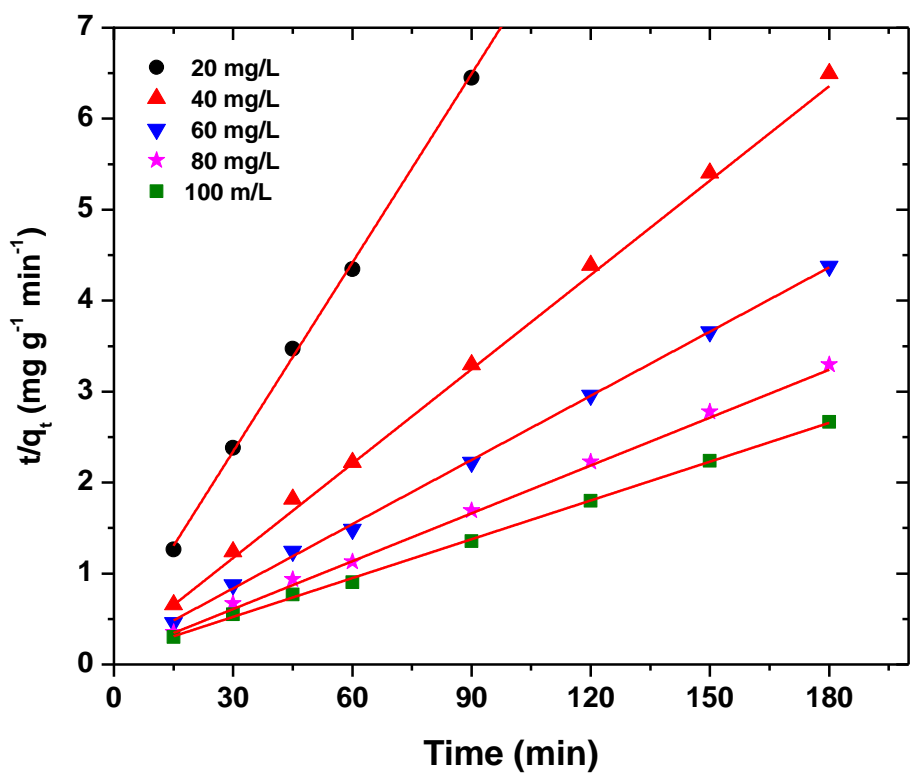

Figure 13. Pseudo-second-order model for dye adsorption by BFO/CFO@PEG nanocomposites. Experimental condition: initial dye concentration $20-100 \mathrm{mg} / \mathrm{L}$, initial solution $\mathrm{pH} 2$, adsorbent dosage $0.06 \mathrm{~g} / \mathrm{L}$, and contact time $40 \mathrm{~min}$.

\subsection{Comparisons}

A brief comparison regarding the application of various nanocomposites for dye removal is very important to check the performance of our system (adsorbent/adsorbate). Some recent examples are given in following.

Zhou et al. (2011) [76] studied effect of application ethylenediamine-modified magnetic chitosan nanoparticles (EMCN) to remove Acid orange 7 and Acid orange 10 from aqueous solution. The result of their research showed that Langmuir isotherm model was the best applicable model and maximum adsorption capacity of applied adsorbent for adsorption Acid orange 7 and Acid orange 10 at temperature of $298 \mathrm{~K}$ was obtained to be 3.47 and $2.25 \mathrm{mmol} / \mathrm{g}$, respectively. Zhang and Kong [77] described the adsorp- 
tion of orange dyes from aqueous solution by synthesized magnetic $\mathrm{Fe}_{3} \mathrm{O}_{4} / \mathrm{C}$ core-shell nanoparticles. The maximum adsorption capacity of synthesized adsorbent for $\mathrm{Cr}$ and MB in studied range was 11.22 and $44.38 \mathrm{mg} / \mathrm{g}$ respectively. Xie et al. [78] in order to adsorption of different dyes such as neutral red (NR), methylene blue (MB), and methyl orange (MO) by magnetic HNT- $\mathrm{Fe}_{3} \mathrm{O}_{4}$ as adsorbent were carried a research. Magnetic HNT- $\mathrm{Fe}_{3} \mathrm{O}_{4}$ shows the best performance for adsorption of MB $(18.44 \mathrm{mg} / \mathrm{g})$. Also adsorption capacity of mentioned adsorbent for adsorption of NR and $\mathrm{MO}$ was 13.62 and $0.65 \mathrm{mg} / \mathrm{g}$ respectively. Inbaraj and Chen (2011) [79], investigated the application of magnetite nanoparticles coated with an anionic biopolymer for dye adsorption. Results of their study present that Redlich-Peterson and Langmuir equations were the best isotherm models. Also, the kinetic data was predicted with pseudo-second-order model as well. The maximum adsorption capacity of synthesized adsorbent was obtained $78.67 \mathrm{mg} / \mathrm{g}$. Debrassi et al. [80,81], were synthesized the magnetic nanoparticles with iron oxides and $\mathrm{N}$-benzyl-O-carboxymethylchitosan by incorporation method. Based on obtained results, the Langmuir-Freundlich model showed the best fitness with experimental data. Maximum adsorption capacity of synthesized adsorbent for MB, CV, and MG adsorption was determined 223.58, 248.42, and $144.79 \mathrm{mg} / \mathrm{g}$. Singh et al. (2011) [82], investigated the efficiency a novel magnetic carbon-iron oxide nanocomposite (MCIONC) to remove of crystal violet dye from aqueous solution. Based on the results of Langmuir model, maximum adsorption of CV under optimum condition was $113.31 \mathrm{mg} / \mathrm{g}$. while in batch experiment, maximum adsorption capacity of adsorbent determined $111.80 \mathrm{mg} / \mathrm{g}$. Yao et al. (2012) [83], explained the dye adsorption ( $\mathrm{MB}$ and $\mathrm{CR}$ ) by magnetic $\mathrm{Fe}_{3} \mathrm{O}_{4} @$ graphene composite from water. The results their study showed each unit of adsorbent could be to remove 45.27 and $33.66 \mathrm{~g} \mathrm{MB}$ and CR, respectively. Mahmoodi (2013) [84] applied the magnetic ferrite nanoparticles (MFN)-alginate composite for dyes removal (Basic Blue 9 (BB9), Basic Blue 41 (BB41), and Basic Red 18 (BR18)).obtained results present that maximum adsorption capacity of (MFN)-alginate composite for adsorption of BB9, BB41, and BR18 was $106 \mathrm{mg} / \mathrm{g}$, $25 \mathrm{mg} / \mathrm{g}$, and $56 \mathrm{mg} / \mathrm{g}$ respectively. Fan et al. (2012) [85] used magnetic chitosan and grapheme oxide composite for methylene blue dye removal from water. The results their research showed under condition of initial concentration of $10 \mathrm{mg} / \mathrm{g}$ and $\mathrm{pH} 10$, maximum adsorption obtained $179.6 \mathrm{mg} / \mathrm{g}$.

\subsection{Perspectives/Limitations}

Adsorption is a very promising technique and some important advantages are be listed below [86]:

- High ability to remove various organic and inorganic pollutants.

- Existence of a wide range of new adsorbent with high adsorption capacity.

- Use of cheap absorbents.

- Fast and simple procedure of removing pollutants.

- The ability to reuse some used adsorbent.

- The cost of the initial investment is cheap.

On the other hand, there are major limitation of the process as [86]:

- Dependence of performance on the type of used adsorbent.

- Low capacity of some adsorbent to remove various pollutants.

- Rapid saturation of some adsorbents and reduction of their adsorption capacity.

- Non-selective pollutant for removing in a binary solution.

- Problems related to desorption of the used adsorbent after the adsorption process.

- Dependence of the adsorption process to various parameters such as temperature, time, and $\mathrm{pH}$.

Nanoparticles that used as adsorbent due to small size, their recovery is very difficult and expensive. Generally, sedimentation and filtration techniques are applied for their separating from aqueous solutions. Uses of the mentioned method have some challenges that reduce the pollution adsorption efficiency. for example blockage of filters due to small 
dimension of nanoparticles, secondary pollution due to spreading of nanoparticles, and reducing of adsorption efficiency due to the tendency of nanoparticles to agglomeration [87]. Therefore, to solve the mentioned problems related to nanoparticles, the solutions have been used. One of the solutions is combination of nanoparticles with materials of larger dimension (active carbon and nanofibers) or combination with magnetic material so that their use and reused become easy, fast, simple, and inexpensive [88].

Moreover, experimental research of dye removal from industrial wastewater by nanoadsorbents at laboratory scale consider only one type contaminant while, in fact, a sample of industrial effluent contains a variety of dyes and contaminants.

Another challenge in that using nanoparticles to remove dye is a costly procedure due to the effort required for preparing nanoparticles as adsorbents. For example TIo2 nanoparticles and CNTs are the materials that use a lot for removing of different pollutant such as dye, while its preparation is complex, toxic and expensive. More importantly, the use of nanoparticles may cause other environmental problems due to its small size and high dispersal ability in water, soil, etc. Hence, it is necessary to investigate the toxicity and performance of nanoparticles before any applications.

\section{Conclusions}

BFO/CFO@PEG nanocomposite was demonstrated to be an efficient adsorbent for adsorption of AB92 from the aqueous solution. The adsorption process was dependent on different conditional parameters such as contact time, solution $\mathrm{pH}$, initial dye concentration, and adsorbent. The effects of conditional parameters including $\mathrm{pH}(2-12)$, initial concentration of dye (20-100 mg/L), adsorbent dosage $(0.02-0.1 \mathrm{~g} / \mathrm{L})$, and contact time (0-180 $\mathrm{min})$ on the adsorption of dye were investigated and then optimized. A high removal efficiency of $88 \%$ was achieved under the optimal condition of adsorbent dosage of $0.06 \mathrm{~g} / \mathrm{L}$, contact time of $60 \mathrm{~min}$, initial dye concentration of $20 \mathrm{mg} / \mathrm{L}$, and solution $\mathrm{pH} 2$. The pseudo-second-order kinetic model and Freundlich isotherm model properly describe the experimental data of this research in adsorption process.

Author Contributions: S.R., A.R., M.S., L.D.H., A.K.T. and G.Z.K.; Writing-original draft preparation S.R., A.R., M.S., L.D.H., A.K.T., and G.Z.K.; Writing-review and editing, S.R., A.R., M.S., L.D.H., A.K.T., and G.Z.K.; Supervision, A.R. and G.Z.K.; All authors have read and agreed to the published version of the manuscript.

Funding: The financial support received for this study from the Greek Ministry of Development and Investments (General Secretariat for Research and Technology) through the research project "Intergovernmental International Scientific and Technological Innovation-Cooperation. Joint declaration of Science and Technology Cooperation between China and Greece" with the topic "Development of monitoring and removal strategies of emerging micro-pollutants in wastewaters" (grant No. $\mathrm{T} 7 \Delta \mathrm{KI}-00220$ ) and it is gratefully acknowledged.

Institutional Review Board Statement: Not applicable.

Informed Consent Statement: Not applicable.

Data Availability Statement: The data presented in this study are available upon request from the corresponding author.

Conflicts of Interest: The authors declare no conflict of interest.

\section{References}

1. Gonawala, K.; Mehta, M.J. Removal of Color from Different Dye Wastewater by Using Ferric Oxide as an Adsorbent. Int. J. Eng. Res. Appl. 2014, 5, 102-109.

2. Liu, X.; Gong, W.; Luo, J.; Zou, C.; Yang, Y.; Yang, S. Selective adsorption of cationic dyes from aqueous solution by polyoxometalate-based metal-organic framework composite. Appl. Surface Sci. 2016, 362, 517-524. [CrossRef]

3. Yagub, M.T.; Sen, T.K.; Afroze, S.; Ang, H.M. Dye and its removal from aqueous solution by adsorption: A review. Adv. Colloid Interface Sci. 2014, 209, 172-184. [CrossRef] [PubMed] 
4. Alkaim, A.F.; Sadik, Z.; Mahdi, D.K.; Alshrefi, S.M.; Al-Sammarraie, A.M.; Alamgir, F.M.; Singh, P.M.; Aljeboree, A.M. Preparation, structure and adsorption properties of synthesized multiwall carbon nanotubes for highly effective removal of maxilon blue dye. Korean J. Chem. Eng. 2015, 32, 2456-2462. [CrossRef]

5. Heydartaemeh, M.R.; Aslani, S.; Ardejani, F. Loess Soil Nanoparticles as A Novel Adsorbent for Adsorption of Green Malachite Dye. J. Chromatogr. Sep. Tech. 2017, 8. [CrossRef]

6. Wang, Y.; Zhang, X.; He, X.; Zhang, W.; Zhang, X.; Lu, C. In situ synthesis of MnO2 coated cellulose nanofibers hybrid for effective removal of methylene blue. Carbohydr. Polym. 2014, 110, 302-308. [CrossRef]

7. Akar, S.T.; Özcan, A.S.; Akar, T.; Özcan, A.; Kaynak, Z. Biosorption of a reactive textile dye from aqueous solutions utilizing an agro-waste. Desalination 2009, 249, 757-761. [CrossRef]

8. Adhoum, N.; Monser, L.; Bellakhal, N.; Belgaied, J.-E. Treatment of electroplating wastewater containing $\mathrm{Cu}^{2+}, \mathrm{Zn}{ }^{2+}$ and $\mathrm{Cr}(\mathrm{VI})$ by electrocoagulation. J. Hazard. Mater. 2004, 112, 207-213. [CrossRef] [PubMed]

9. Santos, M.R.G.; Goulart, M.O.F.; Tonholo, J.; Zanta, C.L.P.S. The application of electrochemical technology to the remediation of oily wastewater. Chemosphere 2006, 64, 393-399. [CrossRef]

10. Meunier, N.; Drogui, P.; Montané, C.; Hausler, R.; Mercier, G.; Blais, J.-F. Comparison between electrocoagulation and chemical precipitation for metals removal from acidic soil leachate. J. Hazard. Mater. 2006, 137, 581-590. [CrossRef] [PubMed]

11. Kyzas, G.Z.; Siafaka, P.I.; Pavlidou, E.G.; Chrissafis, K.J.; Bikiaris, D.N. Synthesis and adsorption application of succinyl-grafted chitosan for the simultaneous removal of zinc and cationic dye from binary hazardous mixtures. Chem. Eng. J. 2015, 259, 438-448. [CrossRef]

12. Tavakolian, M.; Wiebe, H.; Sadeghi, M.A.; van de Ven, T.G.M. Dye Removal Using Hairy Nanocellulose: Experimental and Theoretical Investigations. ACS Appl. Mater. Interfaces 2020, 12, 5040-5049. [CrossRef] [PubMed]

13. Sharma, P.R.; Sharma, S.K.; Lindström, T.; Hsiao, B.S. Nanocellulose-Enabled Membranes for Water Purification: Perspectives. Adv. Sustain. Syst. 2020, 4, 1900114. [CrossRef]

14. Cheng, J.; Zhan, C.; Wu, J.; Cui, Z.; Si, J.; Wang, Q.; Peng, X.; Turng, L.-S. Highly Efficient Removal of Methylene Blue Dye from an Aqueous Solution Using Cellulose Acetate Nanofibrous Membranes Modified by Polydopamine. ACS Omega 2020, 5, 5389-5400. [CrossRef] [PubMed]

15. Li, H.; Cao, X.; Zhang, C.; Yu, Q.; Zhao, Z.; Niu, X.; Sun, X.; Liu, Y.; Ma, L.; Li, Z. Enhanced adsorptive removal of anionic and cationic dyes from single or mixed dye solutions using MOF PCN-222. RSC Adv. 2017, 7, 16273-16281. [CrossRef]

16. Le, H.Q.; Sekiguchi, Y.; Ardiyanta, D.; Shimoyama, Y. $\mathrm{CO}_{2}$-Activated Adsorption: A New Approach to Dye Removal by Chitosan Hydrogel. ACS Omega 2018, 3, 14103-14110. [CrossRef]

17. Ali, A.; Ing, A.W.C.; Abdullah, W.R.W.; Hamzah, S.; Azaman, F. Preparation of high-performance adsorbent from low-cost agricultural waste (Peanut husk) using full factorial design: Application to dye removal. Biointerface Res. Appl. Chem. 2020, 10, 6619-6628.

18. Ali, S.F.A.; Gad, E.S. Investigation of an adsorbent based on novel starch/chitosan nanocomposite in extraction of indigo carmine dye from aqueous solutions. Biointerface Res. Appl. Chem. 2020, 10, 5556-5563.

19. Anuar, F.I.; Hadibarata, T.; Syafrudin, M.; Fona, Z. Removal of procion red MX-5B from aqueous solution by adsorption on parkia speciosa (Stink bean) peel powder. Biointerface Res. Appl. Chem. 2020, 10, 4774-4779.

20. Cotrim, A.C.M.; França, E.L.; França, A.C.H.; Martins, J.S.; Silva, K.P.G.; Ghalfi, Y.C.; Machado, I.T.; Tozetti, I.A. Effect of polyethylene glycol microspheres adsorbed with melatonin on oxidative stress and viscosity of cervical mucus samples infected with human papillomavirus. Biointerface Res. Appl. Chem. 2020, 10, 6757-6772.

21. El-Desouky, M.G.; Hassan, N.; Shahat, A.; El-Didamony, A.; El-Bindary, A.A. Synthesis and characterization of porous magnetite nanosphere iron oxide as a novel adsorbent of anionic dyes removal from aqueous solution. Biointerface Res. Appl. Chem. 2021, 11, 13377-13401.

22. Iroha, N.B.; Maduelosi, N.J. Corrosion inhibitive action and adsorption behaviour of justicia secunda leaves extract as an eco-friendly inhibitor for aluminium in acidic media. Biointerface Res. Appl. Chem. 2021, 11, 13019-13030.

23. Kassimi, A.E.; Achour, Y.; Himri, M.E.; Laamari, M.R.; Haddad, M.E. High efficiency of natural Safiot Clay to remove industrial dyes from aqueous media: Kinetic, isotherm adsorption and thermodynamic studies. Biointerface Res. Appl. Chem. 2021, 11, 12717-12731.

24. Kit, N.H.; Hadibarata, T.; Yuniarto, A.; Sari, A.A. Removal of triphenylmethane dye from aqueous solutions through an adsorption process over waste materials. Biointerface Res. Appl. Chem. 2020, 10, 5772-5779.

25. Salim, N.A.A.; Fulazzaky, M.A.; Puteh, M.H.; Khamidun, M.H.; Yusoff, A.R.M.; Abdullah, N.H.; Ahmad, N.; Lazim, Z.M.; Nuid, M. Adsorption of phosphate from aqueous solution onto iron-coated waste mussel shell: Physicochemical characteristics, kinetic, and isotherm studies. Biointerface Res. Appl. Chem. 2021, 11, 12831-12842.

26. Shaikh, T.M.A. Adsorption of $\mathrm{pb}(\mathrm{II})$ from wastewater by natural and synthetic adsorbents. Biointerface Res. Appl. Chem. 2020, 10, 6522-6539.

27. Sharma, A.; Sharma, P.K.; Malviya, R. Role of different parameters and mathematical models for metal ions adsorption from industrial waste water. Biointerface Res. Appl. Chem. 2020, 10, 5516-5523.

28. Vasylyeva, H.; Mironyuk, I.; Strilchuk, M.; Tryshyn, V.; Gaidar, O.; Vasyliev, O. Adsorption of zirconium ions by X-type zeolite. Biointerface Res. Appl. Chem. 2021, 11, 13421-13431. 
29. Khan, M.A.; Momina; Siddiqui, M.R.; Otero, M.; Alshareef, S.A.; Rafatullah, M. Removal of rhodamine b from water using a solvent impregnated polymeric dowex 5wx8 resin: Statistical optimization and batch adsorption studies. Polymers 2020, 12, 500. [CrossRef]

30. Liakos, E.V.; Mone, M.; Lambropoulou, D.A.; Bikiaris, D.N.; Kyzas, G.Z. Adsorption evaluation for the removal of nickel, mercury, and barium ions from single-component and mixtures of aqueous solutions by using an optimized biobased chitosan derivative. Polymers 2021, 13, 232. [CrossRef]

31. Mohammadi, L.; Rahdar, A.; Khaksefidi, R.; Ghamkhari, A.; Fytianos, G.; Kyzas, G.Z. Polystyrene magnetic nanocomposites as antibiotic adsorbents. Polymers 2020, 12, 1313. [CrossRef]

32. Mone, M.; Lambropoulou, D.A.; Bikiaris, D.N.; Kyzas, G. Chitosan grafted with biobased 5-hydroxymethyl-furfural as adsorbent for copper and cadmium ions removal. Polymers 2020, 12, 1173. [CrossRef] [PubMed]

33. Pham, T.D.; Vu, T.N.; Nguyen, H.L.; Le, P.H.P.; Hoang, T.S. Adsorptive removal of antibiotic ciprofloxacin from aqueous solution using protein-modified nanosilica. Polymers 2020, 12, 57. [CrossRef] [PubMed]

34. Shaipulizan, N.S.; Jamil, S.N.A.M.; Kamaruzaman, S.; Subri, N.N.S.; Adeyi, A.A.; Abdullah, A.H.; Abdullah, L.C. Preparation of ethylene glycol dimethacrylate (EGDMA)-based terpolymer as potential sorbents for pharmaceuticals adsorption. Polymers 2020, 12, 423. [CrossRef] [PubMed]

35. Ofomaja, A.E. Sorption dynamics and isotherm studies of methylene blue uptake on to palm kernel fibre. Chem. Eng. J. 2007, 126, 35-43. [CrossRef]

36. Mohmood, I.; Lopes, C.B.; Lopes, I.; Ahmad, I.; Duarte, A.C.; Pereira, E. Nanoscale materials and their use in water contaminants removal-A review. Environ. Sci. Pollut. Res. 2013, 20, 1239-1260. [CrossRef]

37. Banerjee, S.; Dubey, S.; Gautam, R.K.; Chattopadhyaya, M.C.; Sharma, Y.C. Adsorption characteristics of alumina nanoparticles for the removal of hazardous dye, Orange G from aqueous solutions. Arab. J. Chem. 2019, 12, 5339-5354. [CrossRef]

38. Benkhaya, S.; M'Rabet, S.; El Harfi, A. Classifications, properties, recent synthesis and applications of azo dyes. Heliyon 2020, 6 , e03271. [CrossRef]

39. Ahmadi, S.; Mohammadi, L.; Rahdar, A.; Rahdar, S.; Dehghani, R.; Adaobi Igwegbe, C.; Kyzas, G.Z. Acid Dye Removal from Aqueous Solution by Using Neodymium(III) Oxide Nanoadsorbents. Nanomaterials 2020, 10, 556. [CrossRef]

40. Ahmadi, S.; Mohammadi, L.; Igwegbe, C.A.; Rahdar, S.; Banach, A.M. Application of response surface methodology in the degradation of Reactive Blue 19 using $\mathrm{H} 2 \mathrm{O} 2 / \mathrm{MgO}$ nanoparticles advanced oxidation process. Int. J. Ind. Chem. 2018, 9, 241-253. [CrossRef]

41. Kamal, S.; Pan, G.T.; Chong, S.; Yang, T.C.K. Ultrasonically induced sulfur-doped carbon nitride/cobalt ferrite nanocomposite for efficient sonocatalytic removal of organic dyes. Processes 2020, 8, 104. [CrossRef]

42. Pham, V.T.; Nguyen, H.T.T.; Nguyen, D.T.C.; Le, H.T.N.; Nguyen, T.T.; Le, N.T.H.; Lim, K.T.; Nguyen, T.D.; Van Tran, T.; Bach, L.G. Process optimization by a response surface methodology for adsorption of Congo red dye onto exfoliated graphite-decorated $\mathrm{MnFe}_{2} \mathrm{O}_{4}$ nanocomposite: The pivotal role of surface chemistry. Processes 2019, 7, 305. [CrossRef]

43. Salem, M.Z.M.; Ibrahim, I.H.M.; Ali, H.M.; Helmy, H.M. Assessment of the use of natural extracted dyes and pancreatin enzyme for dyeing of four natural textiles: HPLC analysis of phytochemicals. Processes 2020, 8, 59. [CrossRef]

44. Saroyan, H.; Kyzas, G.Z.; Deliyanni, E.A. Effective dye degradation by graphene oxide supported manganese oxide. Processes 2019, 7, 40. [CrossRef]

45. Trinh, B.S.; Le, P.T.; Werner, D.; Phuong, N.H.; Luu, T.L. Rice husk biochars modified with magnetized iron oxides and nano zero valent iron for decolorization of dyeing wastewater. Processes 2019, 7, 660. [CrossRef]

46. Yang, H.; Liu, M.; Lin, Y.; Yang, Y. Simultaneous enhancements of remanence and (BH)max in BaFe12O19/CoFe2O4 nanocomposite powders. J. Alloys Compd. 2015, 631, 335-339. [CrossRef]

47. Radmanesh, M.A.; Seyyed Ebrahimi, S.A. Synthesis and magnetic properties of hard/soft SrFe $12 \mathrm{O} 19 / \mathrm{Ni} 0.7 \mathrm{Zn} 0.3 \mathrm{Fe} 2 \mathrm{O} 4$ nanocomposite magnets. J. Magn. Magn. Mater. 2012, 324, 3094-3098. [CrossRef]

48. Wang, Y.; Huang, Y.; Wang, Q. Preparation and magnetic properties of $\mathrm{BaFe}_{12} \mathrm{O}_{19} / \mathrm{Ni}_{0.8} \mathrm{Zn}_{0.2} \mathrm{Fe}_{2} \mathrm{O}_{4}$ nanocomposite ferrite. J. Magn. Magn. Mater. 2012, 324, 3024-3028. [CrossRef]

49. Sivashankar, R.; Sathya, A.B.; Vasantharaj, K.; Sivasubramanian, V. Magnetic composite an environmental super adsorbent for dye sequestration-A review. Environ. Nanotechnol. Monit. Manag. 2014, 1, 36-49. [CrossRef]

50. Aguirre-Araque, J.S.; Guimaraes, R.R.; Toma, H.E. Chemistry of ternary monocarboxyterpyridine-bipyridine-trimercaptotriazine ruthenium complexes and application in dye sensitized solar cells. Polyhedron 2020, 182, 114513. [CrossRef]

51. Aiswarya, K.M.; Raguram, T.; Rajni, K.S. Synthesis and characterisation of nickel cobalt sulfide nanoparticles by the solvothermal method for dye-sensitized solar cell applications. Polyhedron 2020, 176, 114267. [CrossRef]

52. Akram, M.A.; Ye, J.; Wang, G.; Shi, L.; Liu, Z.; Lu, H.; Zhang, S.; Ning, G. Bifunctional chemosensor based on a dye-encapsulated metal-organic framework for highly selective and sensitive detection of $\mathrm{Cr}_{2} \mathrm{O}^{2-}$ and $\mathrm{Fe}^{3+}$ ions. Polyhedron 2020, 185 , 114604 . [CrossRef]

53. Alimard, P. Fabrication and kinetic study of Nd-Ce doped $\mathrm{Fe}_{3} \mathrm{O}_{4}$-chitosan nanocomposite as catalyst in Fenton dye degradation. Polyhedron 2019, 171, 98-107. [CrossRef]

54. Du, X.; He, H.; Du, L.; Li, W.; Wang, Y.; Jiang, Q.; Yang, L.; Zhang, J.; Guo, S. Porous Pr(III)-based organic framework for dye-adsorption and photo degradation with (4,5)-c net. Polyhedron 2019, 171, 221-227. [CrossRef] 
55. Fan, C.; Zong, Z.; Zhang, X.; Su, B.; Zhu, Z.; Bi, C.; Fan, Y. Syntheses, structural diversity and photo-degradation and dye adsorption properties of novel $\mathrm{Ni}$ (II)/Co(II) coordination polymers modulated by 4-(4-carboxylphenylmethylthio)benzoic acid ligand. Polyhedron 2019, 170, 515-522. [CrossRef]

56. Ghomshehzadeh, S.G.; Nobakht, V.; Pourreza, N.; Mercandelli, P.; Carlucci, L. A new pillared Cd-organic framework as adsorbent of organic dyes and as precursor of CdO nanoparticles. Polyhedron 2020, 176, 114265. [CrossRef]

57. $\mathrm{Hu}, \mathrm{Q} . ;$ Zheng, Q.M.; Ma, X.R.; Lai, Z.Z.; Ye, T.Q.; Qin, L. One luminescence probe and the impact of dye-adsorption on the luminescent property. Polyhedron 2020, 177, 114323. [CrossRef]

58. Liu, X.; Hao, C.; Cui, L.; Wang, Y. An anionic cadmium-organic framework with an uncommon 3,3,4,8-c network for efficient organic dye separation. Polyhedron 2020, 188, 114685. [CrossRef]

59. Debnath, B.; Roy, A.S.; Kapri, S.; Bhattacharyya, S. Efficient Dye Degradation Catalyzed by Manganese Oxide Nanoparticles and the Role of Cation Valence. Chem. Select 2016, 1, 4265-4273. [CrossRef]

60. Biglari, H. Evaluation of Phenol Removal from Aqueous Solution by Banana Leaf Ash. J. Glob. Pharma Technol. 2017, 9, $20-28$.

61. Bazrafshan, E.; Kord Mostafapour, F.; Faridi, H.; Farzadkia, M.; Sargazi, S.; Sohrabi, A.L.I. Removal of 2, 4-dichlorophenoxyacetic acid (2, 4-d) from aqueous environments using single-walled carbon nanotubes. Health Scope 2013, 2, 39-46. [CrossRef]

62. Derakhshani, E.; Naghizadeh, A.; Khodadadi, M. Application of Different Isotherm Models for Humic Acid Adsorption on to Bentonite and Montmorillonite Nanoparticles. Health Scope 2017, 6, e40416.

63. Salas, G.; Veintemillas-Verdaguer, S.; Morales, M.d.P. Relationship between physico-chemical properties of magnetic fluids and their heating capacity. Int. J. Hyperth. 2013, 29, 768-776. [CrossRef]

64. Crini, G. Non-conventional low-cost adsorbents for dye removal: A review. Bioresour.Technol. 2006, 97, 1061-1085. [CrossRef] [PubMed]

65. Shahmoradi, B.; Maleki, A.; Byrappa, K. Removal of Disperse Orange 25 using in situ surface-modified iron-doped TiO 2 nanoparticles. Desalin. Water Treat. 2015, 53, 3615-3622. [CrossRef]

66. Rahmani, A.; Norozi, R.; Samadi, M.T.; Afkhami, A. Hexavalent Chromium Removal from Rqueous Solution by Produced Iron Nanoparticles. Iran. J. Health Environ. 2009, 1, 67-74.

67. Bazrafshan, E.; Kord Mostafapour, F.; Rahdar, S.; Mahvi, A.H. Equilibrium and thermodynamics studies for decolorization of Reactive Black 5 (RB5) by adsorption onto MWCNTs. Desalin. Water Treat. 2015, 54, 2241-2251. [CrossRef]

68. Fazlzadeh, M.; Rahmani, K.; Zarei, A.; Abdoallahzadeh, H.; Nasiri, F.; Khosravi, R. A novel green synthesis of zero valent iron nanoparticles (NZVI) using three plant extracts and their efficient application for removal of $\mathrm{Cr}(\mathrm{VI})$ from aqueous solutions. Adv. Powder Technol. 2017, 28, 122-130. [CrossRef]

69. Ganesan, P.; Kamaraj, R.; Vasudevan, S. Application of isotherm, kinetic and thermodynamic models for the adsorption of nitrate ions on graphene from aqueous solution. J. Taiwan Inst. Chem. Eng. 2013, 44, 808-814. [CrossRef]

70. Rahdar, A.; Ahmadi, S.; Fu, J.; Rahdar, S. Iron oxide nanoparticle preparation and its use for the removal of fluoride from aqueous solution: Application of isotherm, kinetic and thermodynamics. Desalin. Water Treat. 2019, 137, 174-182. [CrossRef]

71. Langmuir, I. The Adsorption of Gases on Plane Surfaces of Glass, Mica and Platinum. J. Am. Chem. Soc. 1918, 40, 1361-1403. [CrossRef]

72. Freundlich, H. Over the adsorption in solution. Z. Phys. Chem. 1906, 57, 385-470.

73. Temkin, M.; Pyzhev, V. Kinetics of ammonia synthesis on promoted iron catalysts. Acta Physicochim. URSS 1940, 12, 327-356.

74. Dubinin, M.M. The Potential Theory of Adsorption of Gases and Vapors for Adsorbents with Energetically Nonuniform Surfaces. Chem. Rev. 1960, 60, 235-241. [CrossRef]

75. Rahdar, S.; Rahdar, A.; Igwegbe, C.; Moghadam, F.; Ahmadi, S. Synthesis and physical Characterization of Nickel oxide nanoparticle and its application study in the Removal of ciprofloxacin from contaminated water by adsorption: Equilibrium and kinetic studies. Desalin. Water Treat. 2019, 141, 386-393. [CrossRef]

76. Zhou, L.; Jin, J.; Liu, Z.; Liang, X.; Shang, C. Adsorption of acid dyes from aqueous solutions by the ethylenediamine-modified magnetic chitosan nanoparticles. J. Hazard. Mater. 2011, 185, 1045-1052. [CrossRef]

77. Zhang, Z.; Kong, J. Novel magnetic $\mathrm{Fe}_{3} \mathrm{O}_{4} \mathrm{C}$ nanoparticles as adsorbents for removal of organic dyes from aqueous solution. J. Hazard. Mater. 2011, 193, 325-329. [CrossRef]

78. Xie, Y.; Qian, D.; Wu, D.; Ma, X. Magnetic halloysite nanotubes/iron oxide composites for the adsorption of dyes. Chem. Eng. J. 2011, 168, 959-963. [CrossRef]

79. Inbaraj, B.S.; Chen, B.H. Bioresour. Technol. J. Bioresour. Technol. 2011, 102, 8868.

80. Debrassi, A.; Baccarin, T.; Demarchi, C.A.; Nedelko, N.; Ślawska-Waniewska, A.; Dłużewski, P.; Bilska, M.; Rodrigues, C.A. Adsorption of Remazol Red 198 onto magnetic N-lauryl chitosan particles: Equilibrium, kinetics, reuse and factorial design. Environ. Sci. Pollut. Res. 2012, 19, 1594-1604. [CrossRef]

81. Debrassi, A.; Corrêa, A.F.; Baccarin, T.; Nedelko, N.; Ślawska-Waniewska, A.; Sobczak, K.; Dłuzewski, P.; Greneche, J.M.; Rodrigues, C.A. Removal of cationic dyes from aqueous solutions using N-benzyl-O-carboxymethylchitosan magnetic nanoparticles. Chem. Eng. J. 2012, 183, 284-293. [CrossRef]

82. Singh, K.P.; Gupta, S.; Singh, A.K.; Sinha, S. Optimizing adsorption of crystal violet dye from water by magnetic nanocomposite using response surface modeling approach. J. Hazard. Mater. 2011, 186, 1462-1473. [CrossRef]

83. Yao, Y.; Miao, S.; Liu, S.; Ma, L.P.; Sun, H.; Wang, S. Synthesis, characterization, and adsorption properties of magnetic Fe 30 4@graphene nanocomposite. Chem. Eng. J. 2012, 184, 326-332. [CrossRef] 
84. Mahmoodi, N.M. Magnetic ferrite nanoparticle-alginate composite: Synthesis, characterization and binary system dye removal. J. Taiwan Inst. Chem. Eng. 2013, 44, 322-330. [CrossRef]

85. Fan, L.; Luo, C.; Sun, M.; Li, X.; Lu, F.; Qiu, H. Preparation of novel magnetic chitosan/graphene oxide composite as effective adsorbents toward methylene blue. Bioresour. Technol. 2012, 114, 703-706. [CrossRef] [PubMed]

86. Crini, G.; Lichtfouse, E. Advantages and disadvantages of techniques used for wastewater treatment. Environ. Chem. Lett. 2019, 17, 145-155. [CrossRef]

87. .Reddy, D.H.K.; Lee, S.-M. Application of magnetic chitosan composites for the removal of toxic metal and dyes from aqueous solutions. Adv. Colloid Interface Sci. 2013, 201, 68-93. [CrossRef]

88. Donia, A.M.; Atia, A.A.; Elwakeel, K.Z. Selective separation of mercury(II) using magnetic chitosan resin modified with Schiff's base derived from thiourea and glutaraldehyde. J. Hazard. Mater. 2008, 151, 372-379. [CrossRef] 